\title{
PENGEMBANGAN PANDUAN PRAKTIKUM ONLINE MENGGUNAKAN SMARTPHONE BERBASIS APLIKASI PHYPOX
}

\author{
Shelin Novitasari, Djeli Alvi Tulandi, Jimmy Lolowang \\ Fakultas Matematika dan Ilmu Pengetahuan Alam, Universitas Negeri Manado \\ email: stakalelumang@gmail.com
}

\begin{abstract}
ABSTRAK
Di era digital saat ini sistim pembelajaran mengalami banyak perubahan. Pembelajaran berbasis online telah menjadi salah satu model pembelajaran dewasa ini yang paling penting dan salah satu model pembelajaran yang memanfaatkan media online seperti Blended leaning atau penggunaan smartphone. Tujuan penelitian ini adalah untuk mengembangkan panduan laboratorium online pada materi pendulum. Tahapan yang telah dilakukan dalam penelitian ini: Mendesain panduan kegiatan laboratorium online mengggunakan handpone berbasis aplikasi phyphox. Pengembangan perangkat lunak ini dilakukan berdasarkan kolaborasi penelitian pengembangan Research and Development (R\&D) meliputi : Tahap Analisis/Pendefinisian ,Tahap Desain, Tahap Pengembangan,Tahap Pengujian dan Evaluasi. Hasil penelitian merekomendasikan bahwa panduan praktikum online menggunakan handpone berbasis aplikasi phyphox pada materi pendulum layak digunakan dalam mengoptimalkan kegiatan praktikum di Jurusan Fisika. Penelitian kolaboratif antara dosen dan masiswa ini juga dapat meningkatkan iklim akademik, melalui optimalisasi interaksi dosenmahasiswa.
\end{abstract}

Kata kunci: Penelitian pengembangan, Praktikum online

\begin{abstract}
In today's digital era, the learning system has undergone many changes. Online-based learning has become one of the most important learning models today and one of the learning models that utilize online media such as Blended learning or the use of smartphones. The purpose of this research is to develop an online laboratory guide on pendulum material. The stages that have been carried out in this study: Designing an online laboratory activity guide using a phyphox application-based cellphone. This software development is carried out based on the research and development research collaboration of Research and Development $(R \& D)$ including: Analysis / Defining Stage, Design Stage, Development Stage, Testing and Evaluation Phase. The results of the study recommend that the online practicum guide using a phyphox application-based handphone on pendulum material is suitable for optimizing practicum activities in the Physics Department. This collaborative research between lecturers and students can also improve the academic climate, through optimizing lecturerstudent interactions.
\end{abstract}

Keywords: Development research, Online practicum 


\section{PENDAHULUAN}

Pembelajaran berbasis online telah menjadi salah satu model pembelajaran dewasa ini yang paling penting. Salah satu model pembelajaran yang memanfaatkan media online adalah Blended leaning. Mengajar fisika dengan blended learning tidak hanya memberi peran utama kepada seorang guru tetapi juga memenuhi kebutuhan belajar mandiri, praktis dan efisien.(Lie L dan Tang T, 2017).

Menurut proses pembelajaran campuran, seorang instruktur/guru dapat mengajar melalui ruang kelas berbasis web, dan dapat juga menyelesaikan kegiatan pengajaran lainnya seperti mempersiapkan pelajaran, tugas, penilaian, menjawab pertanyaan. Selain pembelajaran kelas tatap muka, siswa dapat dengan bebas menyelesaikan kegiatan pembelajaran lainnya seperti pembelajaran online, pekerjaan rumah online, pertanyaan online, diskusi dan menjawab lewat perangkat seluler, dan lain lain diluar kelas.

Kementerian Pendidikan dan Kebudayaan (Kemendikbud) menerbitkan Surat Edaran Nomor 15 Tahun 2020 tentang Pedoman Penyelenggaraan Belajar Dari Rumah Dalam Masa Darurat Penyebaran Covid-19. Tujuan dari pelaksanaan Belajar Dari Rumah (BDR) adalah memastikan pemenuhan hak peserta didik untuk mendapatkan layanan pendidikan selama darurat Covid-19, melindungi warga satuan pendidikan dari dampak buruk Covid19, mencegah penyebaran dan penularan Covid-19 di satuan pendidikan dan memastikan pemenuhan dukungan psikososial bagi pendidik, peserta didik, dan orang tua.

Metode dan media pelaksanaan Belajar Dari Rumah(BDR) dilaksanakan dengan dengan Pembelajaran Jarak Jauh (PJJ) yang dibagi kedalam dua pendekatan yaitu pembelajaran jarak jauh dalam jaringan(daring) dan luar jaringan(luring).

Dampak dari pandemic covid-19 meluas ke seluruh sektor kehidupan manusia di seluruh dunia. Di Indonesia di keluarkan Peraturan Menteri Kesehatan (Permenkes) RI Nomor 9 Tahun 2020 tentang Pedoman Pembatasan Sosial Berskala Besar dalam rangka percepatan penanganan Corona Virus Disease 2019 (Covid-19). Merujuk pada Peraturan Menteri Kesehatan (Permenkes) RI Nomor 9 Tahun 2020, PSBB adalah pembatasan kegiatan tertentu penduduk dalam suatu wilayah yang diduga terinfeksi corona virus disease 2019
(Covid-19) sedemikian rupa untuk mencegah kemungkinan penyebarannya. Sejalan dengan pemberlakuan PSBB, kemudian diikuti dengan himbauan-himbauan work from home dan learning from home. Khusus dalam dunia Pendidikan pembelajaran daring akhirnya dijalankan walaupun masih banyak kendala antara lain ketersediaan akses internet, ketrampilan siswa dan guru/dosen dalam pemanfaatan teknologi informasi.

Pelaksanaan pembelajaran terkait praktikum akhirnya harus menggunakan laboratorium virtual( e-praktikum), karena tidak mungkin menggunakan alat labortorium yang ada mengingat pembelajar berada di daerah daerah. Selain keterbatasan SDM, prodi Pendidikan Fisika UNIMA juga menghadapi persoalan keterbatasan sarana khususnya laboratorium. Sarana laboratorium sangat penting peranannya dalam penyelenggaraan pendidikan Fisika, sehingga setiap universitas atau institut harus memilikinya (Peraturan Pemerintah Nomor 60, 1999). Laboratorium juga telah menjadi salah satu parameter penilaian akreditasi (BAN-PT, 2008: 25; ABET, 2009: 4), dan sebagai salah satu standar mutu dalam Sistem Penjaminan Mutu Perguruan Tinggi (DEPDIKNAS, 2008: 119120). Dalam proses pembelajaran, laboratorium berguna menumbuhkan keterampilan-keterampilan tertentu (Kozma, Belle \& Williams, 1978: 341), dan sebagai sarana untuk membangkitkan minat, keingintahuan (curiosity), kemampuan berpikir dalam orde tinggi (higher order thinking) serta kemampuan memahami konsep (Sunal, Wright \& Sundberg, 2008: 2).

Beberapa aplikasi E-praktikum yang biasa di gunakan dalam pebelajaran fisika adalah Phyphox. Aplikasi Phyphox dikembangkan oleh Aachen University untuk membantu melakukan eksperimen sains menggunakanm smartphone. Aplikasi Phyphox memanfaatkan sensor yang terpasang di smartphone sehingga tidak diperlukan alat ukur tambahan dalam pemanfaatannya. Aplikasi dapat diunduh di App Store atau Google Play.

Perangkat seluler saat ini sangat cerdas karena mengandung sensor yang menerima data dari lingkungan sekitar kita. Smartphone umumnya sudah dilengkapi dengan barometer, sensor cahaya, magnetometer, giroskop, akselerometer, dan mikrofon. Dengan 
memanfaatkan sensor di ponsel kalian, kalian dapat melakukan penyelidikan ilmiah terhadap kecepatan, akselerasi, magnet, suara, frekuensi, kecerahan, tekanan, dan orientasi. Dengan adanya perangkat cerdas ini kita dapat melakukan peragaan magnetic spectrum langsung dan mengambil data, mengukur jarak melalui gema atau menganalisis frekuensi dan periode pegas osilator saat menggunakan smartphone. Selain itu ada Lab online(Olabs) didasarkan pada gagasan bahwa eksperimen laboratorium dapat diajarkan menggunakan Internet, lebih efisien dan lebih murah. Laboratorium juga dapat disediakan bagi siswa yang tidak memiliki akses ke laboratorium fisik atau di mana peralatan tidak tersedia karena langka atau mahal. Ini membantu mereka bersaing dengan siswa di sekolah yang lebih lengkap dan menjembatani kesenjangan digital dan jarak geografis. Eksperimen dapat diakses kapan saja dan di mana saja, mengatasi kendala waktu yang dirasakan ketika memiliki akses ke laboratorium fisik hanya untuk waktu yang singkat. Beberapa pertimbangan perlunya epraktikum karena pada laboratorium fisik atau Laboratorium riel ada kendala waktu, melibatkan jumlah siswa yang besar sementara peralatan terbatas dari sisi jumlah dan kualitas alat, biaya, pertimbangan lingkungan, dan pertimbangan keselamatan. Hal lainnya adalah persyaratan staf yang kompeten dan terlatih yang dapat memberikan bimbingan yang efektif kepada siswa. Semua faktor ini meningkatkan biaya pengoperasian dan pemeliharaan laboratorium fisik/laboratorium riel. OLabs merupakan sistem bimbingan belajar perseorangan yang memungkinkan siswa melakukan eksperimen kapan saja dan di mana saja. Labs online(OLabs) mendukung gaya belajar dan preferensi belajar melalui tutorial, animasi, video, grafik, simulasi dan ringkasan dengan informasi rinci. Setiap lab dirancang untuk memberikan siswa pengalaman kehidupan nyata untuk meningkatkan pembelajaran dan pemahaman siswa tentang setiap eksperimen. Ada prosedur online untuk setiap eksperimen yang memberikan petunjuk langkah demi langkah terperinci tentang cara melakukan eksperimen di lab tradisional dan juga cara menggunakan simulator online. Animasi membantu siswa memperoleh pemahaman tentang cara melakukan percobaan dengan petunjuk, tip alat yang menunjukkan pengukuran, cara kerja peralatan dan informasi relevan lainnya. Simulasi dapat digunakan untuk melakukan percobaan secara interaktif. Eksperimen dapat dilakukan dengan mengklik tab 'Simulasi' dan mengikuti petunjuk langkah demi langkah seperti yang diberikan di tab 'Prosedur'. Fasilitas juga disediakan bagi siswa untuk mengecek hasil yang diperoleh.

Seorang siswa yang telah melakukan percobaan online dapat melakukan evaluasi diri melalui modul Viva Voce. Ini melacak apa yang siswa ketahui dan pelajari tentang suatu topik. Ini dapat digunakan sebelum, selama, dan setelah melakukan percobaan. Data yang diperoleh dari modul ini dicatat untuk dianalisis nanti.

\section{METODE PENELITIAN}

Penelitian ini menggunakan metode penelitian dan pengembangan (and Development). Model pengembangan dalam penelitian ini mengadaptasi model pengembangan Borg \& Gall. Menggunakan 8 tahapan dari model pengembangan Borg \& Gall yaitu studi pendahuluan, perencanaan, pengembangan produk, uji coba terbatas, revisi produk, uji lapangan, penyempurnaan produk akhir, dan diseminasi secara terbatas.

Subjek dalam penelitian pengembangan adalah mahasiswa semester 3 prodi Pendidikan Fisika Unima.

\section{HASIL DAN PEMBAHASAN}

Berdasarkan rancangan pengembangan seperti yang dijelaskan pada bab III, maka hasil penelitian ini disesuaikan dengan prosedur atau langkah-langkah rancangan pengembangan 4D (Define, Design, Develop, dan Disseminate) yang ditempuh yaitu menyesesuaikan dengan jadwal dari subyek penelitian.

\section{Tahap Pendefinisian}

Hasil tahap ini adalah menetapkan dan mendefinisikan masalah-masalah yang dihadapi oleh jurusan fisika UNIMA terlebih dalam pembelajaran di laboratorium. Dalam menentukan dan menetapkan masalah-masalah diawali dengan analisis tujuan dari batasan materi yang dikembangkan perangkatnya. Hasil dari tahap pendefinisian adalah penentuan perangkat yang akan dikembangkan. Tahap ini meliputi 5 langkah pokok, yaitu:

i. Analisis Ujung Depan (Front-End Analysis)

Hasil Analisis ujung depan yaitu memunculkan 
dan menetapkan masalah dasar yang dihadapi dalam pembelajaran fisika di jurusan fisika UNIMA antara lain belum adanya panduan praktikum khususnya laboratorium online dengan aplikasi phyphox untuk pembelajaran Blended Learning dan terutama melakukan eksperimen mandiri di rumah di era pandemic covid-19.

ii. Analisis Mahasiswa (Learner Analysis) Hasil dari analisis ini, mahasiswa merasa akan mendapat kesulitan jika tidak ada panduan praktikum disamping itu mahasiswa membutuhkan referensi teori yang memadai.mahasisiwa akan sangat terbantu jika dapat melaksanakan praktikum secara online di ruma masing-masing.

iii. Analisis Tugas (Task Analysis)

Hasil dari Analisis tugas yaitu tugas yang dikerjakan belum memenuhi standar referensi teori dan prosedur pelaksanaan praktikum belum memadai. Tugas tugas praktikum akan memudahkan mahasiswa karena lewat epraktikum

iv. Analisis Konsep (Concept Analysis)

Hasil dari analisis konsep ini yaitu panduan praktikum harus memiliki referensi yang lengkap untuk membantu proses pembelajaran di laboratorium. Konsep fisika yang didapatkan yaitu tentang tumbukan dan efek dopler. Namun dengan adanya pandun ini memungkinkan mahasiswa melakukan percobaan online untuk konsep fisika yang lain. v. Perumusan Tujuan Praktikum (Specifying Instructional Objectives)

Pada langkah ini dilakukan perumusan tujuan praktikum dan indikator ketercapaian pada panduan praktikum alat generator satu fase dan tiga fase setelah melakukan pembelajaran.

\section{Tahap Perancangan}

Perancangan ini dimulai dengan mempelajari aplikasi phyphox melalui youtube dalam Bahasa Jerman di ubah ke Bahasa Indonesia, kemudian menuliskan secara sistimatis langkah langkah percobaan. Terlebih dahulu peneliti melakukan ujicoba aplikasi phyphox. Pada tahap perancangan meliputi:

a. Peneliti membuat garis-garis besar panduan praktikum berdasarkan langkahlangkah pembelajaran model pembelajaran .

b. Peneliti menyusun teori dasar pertanyaan pengantar untuk panduan praktikum yang akan membantu mahasiswa dalam kegiatan laboratorium. c. Menentukan jenis huruf, ukuran huruf, spasi, tata letak dari bagian-bagian panduan praktikum yang akan dibuat.

d. Peneliti membuat desain untuk panduan praktikum agar panduan dapat terlihat lebih menarik untuk digunakan.

e. Peneliti menyusun Draft aspek dari instrumen penelitian yang akan dijadikan acuan kelayakan dan kualitas panduan praktikum.

f. Peneliti menyusunan tes untuk mengukur keefektifan panduan praktikum terhadap kemampuan penalaran fisika siswa.

Pada tahap ini dilakukan penilaian reviewer oleh tim ahli/pakar dibidang praktikum fisika online. Penilaian dilakukan oleh 2 pakar, yang menilai desain dan isi panduan praktikum dari peneliti. Tim ahli/pakar menilai 2 bagian yaitu desain secara umum dan kelengkapan rancangan panduan praktikum berdasarkan tujuan yang ingin di capai

Untuk bagian desain secara umum aspek yang diamati antara lain derajat keinovatifan, tingkat kreativitas, orginalitas, keberfungsian, dan kemanfaatannya bagi jurusan. Untuk bagian kelengkapan panduan praktikum antara lain orientasi, merumuskan masalah, merumuskan hipotesis, menentukan variabel, merangkai percobaan, mengumpulkan data, menguji hipotesis, dan merumuskan kesimpulan.

Tim ahli/pakar pertama melakukan penilaian sebanyak satu kali baik desain secara umum maupun kelengkapan panduan praktikum dapat direkomendasikan untuk pelaksanaan panduan praktikum tapi harus ditingkatkan pada bagian kelengkapan rancangan penuntun berdasarkan tujuan yang ingin dicapai yaitu di bagian data dan analisis data, kemudian dianalisis berdasarkan skor penilaian mencapai $91,66 \%$ dan panduan praktikum yang dinilai oleh pakar masuk dalam kriteria baik.

Tim ahli/pakar kedua melakukan penilaian sebanyak dua kali. Pada penilaian pertama, pakar memberikan masukan untuk perbaikan panduan, yaitu menambahkan variabel yang akan di ukur. Pada penilaian kedua, pakar memberikan masukan yaitu untuk merubah kata pada tujuan praktikum. Maka dari hasil tersebut peneliti melakukan revisi panduan. kemudian pada tahap kedua, setelah dianalisis kriteria penilaian mencapai $91,66 \%$ panduan praktikum layak dan direkomendasikan untuk digunakan dalam praktikum.

Tahap Pengembangan Panduan Praktikum Setelah peneliti melewati beberapa tahap 
penelitian dengan menggunakan model 4D, panduan praktikum sudah dibuat dan dirancang sedemikian rupa sesuai model pembelajaran berpraktikum. Pembuatan panduan praktikum ini, pada bagian desain secara umum aspek yang diamati antara lain derajat keinovatifan, tingkat kreatifitas, originalitas keberfungsian, tingkat keefektifan penggunaan, efisiensi penggunaan, estetika, dan kemanfaatannya bagi jurusan. Untuk bagian kelengkapan panduan praktikum antara lain merumuskan masalah, merumuskan hipotesis, penyusunan peralatan, menyusun prosedur dalam melakukan kegiatan, data dan analisis data dan menarik kesimpulan. Panduan praktikum yang dihasilakn digunakan dalam menguji kebefungsian alat praktikum generator satu fase dan tiga fase, dimana panduan praktikum yang dibuat berdasarkan pada materi yang disesuaikan dengan praktikum materi getaran khususnya pendulum.

\section{Uji Coba Kelompok Kecil}

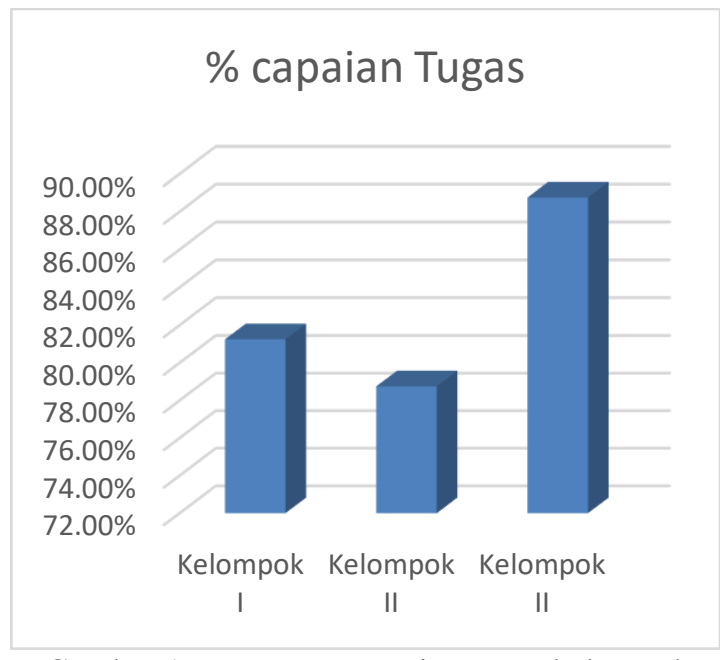

Gambar 1. Persentase capaian tugas kelompok

Dalam kegiatan praktikum, kelompok kecil terdiri dari 3 kelompok, masing-masing kelompok terdiri dari 3 mahasiswa. Pada uji coba kelompok kecil nilai capaian yang dicapai adalah $81,25 \%, 78,75 \%, 88,75 \%$ sehingga presentasi capaian tugas, dilihat ketiga kelompok memperoleh nilai rata-rata $82,91 \%$, sehingga panduan praktikum masuk dalam kategori layak.

Ada 3 kelompok mahasiswa yang mengikuti praktikum online untuk materi pendulum. Hasil perhitungan terlihat bahwa 47\% respon kelompok mahasiswa memilih pilihan kategori "Sangat bermanfaat (SB)", $53 \%$ respon kelompok mahasiswa memberi pilihan kategori "Bermanfaat (B)" yang berarti penilaian positif dari kelompok mahasiswa terhadap indikator-indikator yang ditanyakan $100 \%$. Tidak ada mahasiswa yang yang memberi pilihan untuk kategori "Kurang Bermanfaat (KB)" dan kategori "Tidak Bermanfaat (TB)".

\section{Tahap Pendiseminasian (Disseminate)}

Proses diseminasi merupakan suatu tahap akhir pengembangan. Tahap diseminasi dilakukan untuk mempromosikan produk pengembangan agar bisa diterima pengguna, baik individu, suatu kelompok, atau sistem. Diseminasi bisa dilakukan di kelas lain dengan tujuan untuk mengetahui efektifitas penggunaan alat penunjang praktikum dalam proses praktikum fisika dasar. Penyebaran dapat juga dilakukan melalui sebuah proses penularan kepada para praktisi praktikum terkait dalam suatu forum tertentu. Bentuk diseminasi ini dengan tujuan untuk mendapatkan masukan, koreksi, saran, penilaian, untuk menyempurnakan produk akhir pengembangan agar siap diadopsi oleh para pengguna produk panduan praktikum ini.

\section{Uji Coba Kelompok Besar}

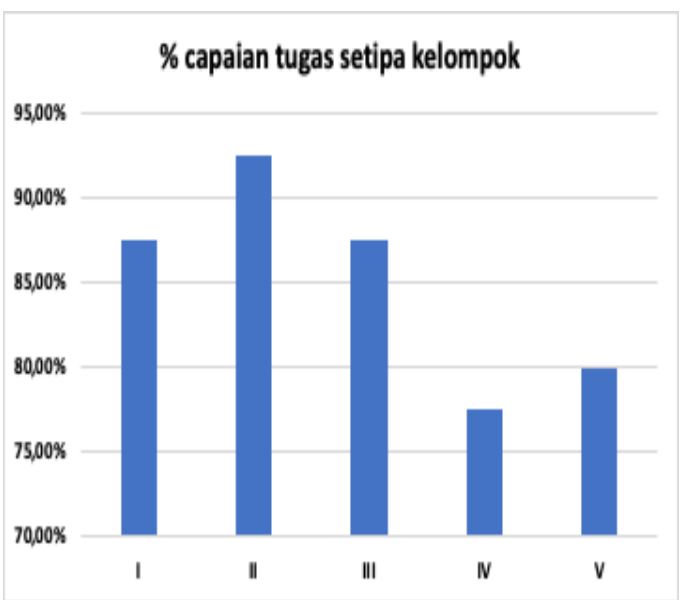

Gambar 2. Persentase capaian tugas uji kelompok besar

\section{Pembahasan}

Perancangan panduan praktikum fisika dasar khususnya panduan praktikum online menggunakan handpone berbasis aplikasi phyphox, dalam proses pengembangannya mendapat saran dan masukan dari tim ahli/reviewer ahli di bidang praktikum dalam rangka validasi desain. Hal ini dilakukan agar produk yang dikembangkan peneliti tersebut 
valid untuk digunakan dilapangan.

Pembuatan panduan praktikum ini, untuk bagian desain secara umum aspek yang diamati antara lain derajat keinovatifan, tingkat kreativitas, originalitas, keberfungsian, tingkat efektifan penggunaan, efisiensi penggunaan, estetika, dan kemaanfaannya bagi jurusan. Untuk bagian kelengkapan panduan praktikum antara lain merumuskan masalah, merumuskan hipotesis, menyusun/merangkai percobaan, menyusun prosedur dan melakukan pengamatan dan analisis data serta merumuskan kesimpulan. Setelah itu diujicobakan pada mahasiswa, untuk mendapatkan kelayakan panduan praktikum.

Pada bagian penilaian reviewer, panduan dapat digunakan pada praktikum fisika dasar, tapi harus diperhatikan adalah tugas yang terkait dalam panduan harus berisi konsepkonsep fisika, tingkat kreatifitas panduan juga efisiensinya dalam kegiatan praktikum. Menurut tim ahli secara keseluruhan panduan yang dikembangkan sudah memenuhi standar untuk diujicobakan pada mahasiswa.

Pada pengujian kelompok kecil dan besar terdapat skor penilain untuk menilai bagaimana pelaksaan praktikum, dalam penilain ini untuk pelaksanaan praktikum ada beberapa indikator yang tercantum dalam kompetensi elemen kerja yaitu (1) merumuskan masalah, (2) merumuskan hipotesis, (3) penyusuna peralatan, (4) menyusun prosedur dalam melakukan kegiatan, (5) data dan analisis data, (6) kesimpulan, (7) membuat inferensi.

Sesuai dengan rancangan, panduan praktikum yang dikembangkan berbasis model pembelajaran inkuiri terbimbing dengan mentoring. Model ini merupakan model pembelajaran yang sesuai dengan hakikat sains dimana mahasiswa dapat menemukan konsep fisika dalam praktikum yang dilakukan. Untuk mengetahui panduan ini layak digunakan, peneliti mengujinya terlebih dahulu ke 3 orang mentor, untuk melihat kemampuan mentor dalam melaksanakan praktikum, hasil uji coba mentor kemudian diperiksa oleh peneliti dan diserahkan ke pakar untuk uji coba pakar, dan dinyatakan layak pada kategori 91,66\%, sesudah itu di ujicobakan ke kelompok kecil yang terdiri dari tiga kelompok dimana setiap kelompok terdiri dari tiga orang mahasiswa dan kelompok besar terdiri dari 6 kelompok dimana setiap kelompok terdiri dari 3 orang mahasiswa, pada ujicoba kelompok kecil setiap kelompok dituntun oleh satu orang mentor dan pada ujicoba kelompok besar setiap mentor menuntun 2 kelompok dalam melaksanakan kegiatan praktikum.

Hasil perhitungan total frekuensi dan persentase. Pada tebel 4.2 terlihat bahwa 37,5\% respon mentor memilih pilihan kategori "Sangat bermanfaat (SB)", 58,3\% respon mentor memberi pilihan kategori "Bermanfaat (B)" dan 4,2\% respon mentor memberi pilihan kategori "Kurang Bermanfaat (KB)" yang berarti penilaian positif dari kelompok mahasiswa terhadap indikator-indikator yang ditanyakan adalah 95,8\%. Dan tidak ada mentor yang memberi pilihan untuk kategori "Tidak Bermanfaat (TB)".

Dalam kegiatan praktikum, kelompok kecil terdiri dari 3 kelompok, masing-masing kelompok terdiri dari 3 orang mahasiswa yang di tuntun oleh satu orang mentor. Pada uji coba kelompok kecil nilai capaian yang dicapai adalah $81,25 \%, 78,75 \%, 88,75 \%$ sehingga presentasi capaian tugas, dilihat ketiga kelompok memperoleh nilai rata-rata $82,91 \%$, sehingga panduan praktikum masuk dalam kategori layak pada uji coba kelompok kecil.

Hasil perhitungan total frekuensi dan persentase. Pada tebel 4.4 terlihat bahwa 47\% respon kelompok mahasiswa memilih pilihan kategori "Sangat bermanfaat (SB)", 53\% respon kelompok mahasiswa memberi pilihan kategori "Bermanfaat (B)" yang berarti penilaian positif dari kelompok mahasiswa terhadap indikator-indikator yang ditanyakan 100\%. Dan tidak ada mahasiswa yang yang memberi pilihan untuk kategori "Kurang Bermanfaat (KB)" dan kategori "Tidak Bermanfaat (TB)".

Hasil dari tanggapan mahasiswa kelompok kecil yang memberikan tanggapan 100\% positif, menandakan panduan praktikum yang dibuat dan diujicobakan pada laboratorium fisika dasar membuat mahasiswa tertarik menggunakan alat tersebut karena bermanfaat dalam kegiatan praktikum. Dimana dalam proses ini dapat meningkatkan minat mahasiswa dalam melaksanakan kegiatan praktikum fisika serta mahasiswa dapat menemukan konsep-konsep fisika dalam kegiatan praktikum. Setelah panduan praktikum di ujicobakan ke kelompok kecil, panduan praktikum akan di ujicobakan ke kelas lain yaitu pada tahap diseminasi.

Proses diseminasi merupakan suatu tahap 
akhir pengembangan. Tahap diseminasi dilakukan untuk mempromosikan produk pengembangan agar bisa diterima pengguna, baik individu, suatu kelompok, atau sistem. Diseminasi bisa dilakukan di kelas lain dengan tujuan untuk mengetahui efektifitas penggunaan alat penunjang praktikum dalam proses praktikum fisika dasar.

Pada uji coba kelompok besar nilai capaian yang dicapai adalah $87,5 \%, 88,75 \%, 90 \%$, $77,5 \%, 80 \%, 83.75 \%$ sehingga presentasi capaian tugas dapat dilihat keenam kelompok memperoleh nilai rata-rata $84,58 \%$, sehingga panduan praktikum masuk dalam kategori layak.

Hasil penelitian yang sudah dibahas di atas merekomendasikan bahwa panduan ini layak di gunakan dalam mengoptimalkan kegiatan praktikum fisika dasar di Jurusan Fisika. Ketersediaan panduan praktikum online ini akan sangat membantu jurusan fisika mrngatasi kendala keterbatasan alat, dan waktu pelaksanaan praktikum. Melalui eksperimen online mahasiswa dapat belajar dimana saja dan kapan saja dan dapat dilaksanakan secara mandiri. Panduan praktikum ini dapat digunakan baik di masa pandemi covid-19 yang mengharuskan belajar di rumah maupun untuk pembelajaran blended learning.

\section{KESIMPULAN}

Hasil penelitian pengembangan panduan laboratorium online menggunakan handpone berbasis aplikasi phyphox pada materi koefisien restitusi dan efek dopler direkomendasikan layak digunakan dalam kegiatan perkuliahan secara blended learning maupun kegiatan mandiri di rumah.

\section{REFERENSI}

ABET. (2010). Criteria for accrediting engineering technology programs. Baltimore: ABET, Inc.

Abdullah, Mikrajuddin. (2017). Fisika Dasar II. Bandung: Instiut Teknologi Bandung.

Alfatah, Arif dan Irwan Yusuf. (2016). Twin Master Outlines Fisika. Bandung: Yarma Widya.

BAN-PT. (2008). Akreditasi program studi sarjana: Buku IIIa borang akreditasi yang diisi oleh program studi. Jakarta: KEMDIKNAS BAN-PT.

BAN-PT. (2011). Direktori sk hasil akreditasi program studi. Diambil pada tanggal 7
Maret 2011, dari http://banpt.depdiknas.go.id/direktori.php.

Chiappetta, E.L., \& Koballa, T.R. (2010). Science Instruction in The Middle and Secondinary Schools Developing Fundamental Knowledge and Skills. USA: Pearson Inc.

Depdikbud. (1999). Penelitian Tindakan Kelas. Jakarta: Depdikbud.

DEPDIKNAS. (2008). Sistem penjaminan mutu perguruan tinggi. Jakarta: Direktorat Jenderal Pendidikan Tinggi DEPDIKNAS.

Frederiksen, Passion for Science https://int.frederiksen.eu/shop/product/mo tor-generator-set--single-phase. Diakses pada tanggal 14 November 2019, pada jam 7:21 AM.

Gagliardi, A. R., Perrier, L., Webster., F., Leslie., K., Bell., M., Levinson., W., Straus., S. E. (2009). Exploring Mentorship as a Strategy to Build Capacity for Knowledge Translation Research \& Practice: Protocol for a Qualitative Study. Biomed Central 4 (55).

Hamzah, Ali dan Muhlisrarini. (2014). Perencanaan dan Strategi Pembelajaran Matematika. Jakarta: Raja Grafindo Persada.

Hegarty-Hazel, E. (1990). The Student Laboratory and the Science Curriculum: An Overview. In E. Hegarty-Hazel (Ed.), The Student Laboratory and the Science Curriculum (pp. 3-26). London: Routledge.

Matialo, B. R. (2017). Pengembangan panduan praktikum fisika untuk alat geometrical optics laser menggunakan model pembelajaran discovery learning, [Skripsi]. Tondano: Universitas Negeri Manado.

Mc Kimm, J., Jolie, C., \& Hatter, M. (2007). Mentoring: Theory and Practice. Preparedness to Practice, Mentoring Scheme. Retrieved from http://www.faculty.londondeanery.ac.uk/l earning/feedback/files/judul.pdf diperoleh pada tanggal 15 Desember 2019.

Mundilarto. (2010). Penilaian Hasil Belajar Fisika. Yogyakarta : P2IS UNY

Nikmah, R., \& Binadja, A. (2015). Pengembangan Diktat Praktikum Berbasis Guided Discovery-Inquiry Bervisi Science, Environment, Technology And 
Society. Jurnal Inovasi Pendidikan Kimia, 9(1), $1506-1516$.

Nurmalia Devi (2012), Pengaruh Program Mentoring dalam Keperawatan Terhadap Penerapan Budaya Keselamatan Pasien di Ruang Rawat Inap RS Islam Sultan Agung Semarang (Tesis), FIK UI.

Nurmalia, Devi., Handayani, H., \& Pujasari, H., (2014). Pengaruh Program Mentoring Terhadap Penerapan Budaya Keselamatan Pasien. Jurnal Managemen Keperawatan . 2(1), 55-63.

Prasetyo, Z. K. (2001). Kapita selekta pembelajaran fisika. Jakarta: Pusat Penerbitan Universitas Terbuka.

Sanjaya, Wina. (2010). Strategi Pembelajaran Berorientasi Standar Proses Pendidikan. Jakarta: Prenada Media Group.

Singer, Susan R., Hilton, Margaret L., Schweingruber, Heidi A. (2005). America's Lab Report: Investigations in High School Science.

Sarlivanti., Adlim., \& Djailani. (2014). Pembelajaran Praktikum Berbasis Inkuiri Terbimbing untuk Meningkatkan Keterampilan Berpikir Kritis dan Keterampilan Proses Sains pada Pokok Bahasan Larutan Penyangga. Jurnal Pendidikan Sains Indonesia, 2(1), 75-86.

Sondakh, K. J. (2017). Pengembangan Panduan Praktikum Fisika Dasar Berbasis Eksperimen Riil Menggunakan Alat System Kit Centripetal Force Dengan Model Inquiry Bebas Yang Dimodifikasi, [Skripsi]. Tondano: Universitas Negeri Manado.

Sugiyono. (2010). Metode Penelitian Kuantitatif Kualitatif dan R\&D. Bandung: Alfabeta.

Sugiyono. (2017). Metode Penelitian Kuantitatif Kualitatif dan R\&D. Bandung: Alfabeta.

Tulandi, Djeli dan Wagania, Hans. (2016). Buku Ajar Pembelajaran Fisika Berbasis Praktikum. (Buku Aajar). Tondano: Universitas Negeri Manado. 